\title{
Changes in Fibrinogen and Total Protein/Albumin Levels During Induction Chemotherapy in Children with Acute Lymphoblastic Leukemia Akut Lenfoblastik Lösemili Çocuklarda Indüksiyon Kemoterapisi Süresince Fibrinojen ve Total Protein/ Albumin Düzeyinde Meydana Gelen Değissiklikler
}

\author{
Zeynep Canan Özdemir, Ayşe Bozkurt Turhan, Özcan Bör \\ Eskisehir Osmangazi University, Department of Pediatrics Division of Pediatric \\ Hematology/Oncology, Eskisehir, Turkey
}

\begin{abstract}
L-Asparaginase is an important drug for treatment of childhood acute lymphoblastic leukemia (ALL). The impairment of protein synthesis due to depletion of asparagine by asparaginase leads to decreases in albumin and deterioration in hemostasis tests. The aims of the present study were to conduct a retrospective evaluation of levels of fibrinogen, total protein/albumin during induction chemotherapy in children with ALL treating according to the BFM 2009 protocol.For this purpose, the laboratory data of 45 pediatric ALL patients in the induction chemotherapy between August 2011 and March 2016 were retrospectively evaluated. This study was approved institutional review board of Eskişehir Osmangazi University Faculty of Medicine (Ethics approval No: 80558721/105). The median fibrinogen level on day 12 was already reduced by $62 \%$ compared to the before treatment values, but this difference was not statistically significant ( $p>0.05$ ). After 15 days of therapy, the level of fibrinogen decreased to $27 \%$, total protein decreased to $89 \%$, albumin decreased to $92 \%$ of the inital value $(\mathrm{p}<0.001, \mathrm{p}<0.01, \mathrm{p}<0.05$, respectively). The lowest fibrinogen and total protein/albumin levels were observed on the 21 st and 27th days of chemotherapy. Thrombotic complication developed in three children (9.3\%). The results showed that the levels of fibrinogen and total protein/albumin were significantly reduced during the induction chemotherapy.

Keywords: induction chemotherapy, L-asparaginase, children, fibrinogen, protein, albumin.
\end{abstract}

Özdemir Z. C., Bozkurt T. A., Bör Ö (2017). Changes in fibrinogen and total protein/albumin levels during induction chemotherapy in children with acute lymphoblastic leukemia, Osmangazi Journal of Medicine, 39(2):45-50. DOI: 10.20515/otd.316147.

Öz: L-Asparaginaz, çocukluk çağı akut lenfoblastik lösemi tedavisinde kullanılan önemli bir ilaçtır.Asparaginaz'ın asparagin tükenmesine bağlı olarak yol açtığı protein sentezindeki bozulma albüminde azalmaya ve hemostaz testlerinde bozulmaya neden olur. Bu çalışmanın amacı, BFM 2009 protokolüne göre tedavi alan akut lenfoblastik lösemili çocuklarda indüksiyon kemoterapisi sırasında fibrinojen, total protein/albumin düzeylerinin retrospektif olarak değerlendirilmesidir. Bu amaçla, Ağustos 2011 ile Mart 2016 tarihleri arasında indüksiyon kemoterapisi alan 45 hastasının laboratuvar parametreleri geriye dönük olarak incelendi. Çalışma için Eskişehir Osmangazi Üniversitesi Klinik Araştırmalar Etik Kurulu'ndan onam alındı (Etik kurul onam numarası: 80558721/105). Onikinci günde medyan fibrinojen düzeyi tedavi başlangıcına göre \%62 oranında azalmıştı. Ancak bu farklılık istatistiksel açıdan anlamlı değildi $(\mathrm{p}>0.05)$. Tedavi sonras1 15. günde medyan fibrinojen düzeyi tedavi öncesi değerin $\% 27$ 'sine, total protein \% 89'una, albumin \%92'sine düşmüştü $(\mathrm{p}<0,001, \mathrm{p}<0,01, \mathrm{p}<0,05$, sirasiyla). Fibrinojen ve total protein/albumin düzeyleri 21. ve 27. günlerde en düşük düzeyde idi. Üç hastada tromboembolik komplikasyon gelişti $(\% 9,3)$. Çalışmanın sonuçları, indüksiyon kemoterapisi süresinde fibrinojen, kan total protein/albumin düzeylerinin önemli ölçüde düștüğünü gösterdi.

Anahtar kelimeler: indüksiyon kemoterapisi, L-Asparaginaz, çocuk, fibrinojen, protein, albümin

Özdemir Z. C., Bozkurt T. A., Bör Ö (2017). Akut Lenfoblastik Lösemili Çocuklarda İndüksiyon Kemoterapisi Süresince Fibrinojen ve Total Protein/Albumin Düzeyinde Meydana Gelen Değişiklikler. Osmangazi Tip Dergisi, 39(2):45-50. DOI: 10.20515/otd.316147.

Yazışma Adresi / Correspondence Address Zeynep Canan ÖZDEMIR

e-mail: efecanan@yahoo.com 


\section{Introduction}

L-Asparaginase is an enzyme with a well documented therapeutic effect in pediatric patients with acute lymphoblastic leukemia (ALL) $(1,2)$. The drug induces a relative asparagine deficiency that leads to the death of human lymphoblasts. However, LAsparaginase has also been shown to be toxic to the liver, pancreas, the central nervous system, and the kidneys (3). The impairment of protein synthesis leads do decreases in many protein such as albumin, insulin and thyroxine-binding globulin (4). Furthermore, it has been reported that treatment with LAsparaginase causes widespread impairment of hemostasis by inhibiting the biosynthesis of hepatic L-asparagine dependent proteins (3). Plasma antithrombin and fibrinogen levels decrease more significantly than any other hemostatic proteins (3). This effect may be associated with an increased tendency to bleeding or thrombosis. These hemostatic modifications induced by L-Asparaginase are relatively rare and milder in children (5). The aim of this retrospective study was to investigate the change in the levels of fibrinogen and total protein/albumin during induction chemotherapy in children with ALL.

\section{Material and Methods}

Forty-five children (1-17 years of age) newlydiagnosed with ALL between

August 2011 and March 2016 were included in this study. All children were treated according to BFM 2009 protocol. The induction chemotherapy regimen consisted of $60 \mathrm{mg} / \mathrm{m}^{2}$ prednisolone (oral) (days 1-33), vincristine $\left(1.5 \mathrm{mg} / \mathrm{m}^{2}\right.$ on days $8,15,22$ and 29 ), daunorubicin $\left(30 \mathrm{mg} / \mathrm{m}^{2}\right.$ on days 8,15 ; standard risk, on day $8,1522,29$ : medium and high risk), Escherichia Coli L-asparaginase $\left(5000 \mathrm{U} / \mathrm{m}^{2}\right.$ on days $12,15,18,21,24,27,30$, and 33).

At the time of diagnosis patients' age, sex, blast percentages in the peripheral blood and bone marrow, leukemia immunophenotype, risk group, sedimentation rate hemogram, fibrinogen and total protein/albumin levels were recorded. Blood samples for fibrinogen and total protein/albumin studies were obtained before the L-Asparaginase infusions. The fibrinogen levels were determined using a commercially available kit (Thromborel-S) an autoanalyser. Total protein and albumin levels were determined with the colorimetric method on a Roche Hitachi Cobas C702 analyser. The patient files were retrospectively assessed and recorded by two physicians and both sets of data were compared.

\section{Exclusion criteria}

Children diagnosed with lymphoma, acute myeloid leukemia, relapsed ALL and not accessible to laboratory data of five children with newly diagnosed leukemia was excluded from the study.

\section{Statistical analysis}

All analyses were performed using the SPSS 21.0 statistics software package (SPSS for Windows 21.0; SPSS, Chicago, IL, USA). The normality of distributions was evaluated with the Kolmogorov Smirnov test. Continuous variables were expressed as mean values \pm standart deviation (SD) and median (interquartiles). The fibrinogen and total protein/albumin levels were compared with nonparametric Friedman's test. $\mathrm{P}<0.05$ was considered statistically significant.

\section{Results}

The ages of the forty-five pediatric patients (23 females and 22 males) with ALL ranged between 1 and 17 years and their median age was 4.5(3-10.2) years. Thirty-seven patients had pre-B ALL (82\%), 4 had pro-B ALL (9\%) and 4 had T-ALL (9\%). Among the patients, $18(40 \%)$ were in the SRG, $21(47 \%)$ were in the IRG, and 6 patients (13\%) were in the HRG. At time of diagnosis, the median hemoglobin value was $7.35 \mathrm{~g} / \mathrm{dl}$ (5.07-9.52), the median leukocyte number was $10.95 \times 10^{9} / \mathrm{L}(4.85-41.78)$, the median platelet number was $81.0 \times 10^{9} / \mathrm{L}(23.75-131.75)$ and the median sedimentation rate was $87.5(62-$ 105.25) $\mathrm{mm} / \mathrm{h}$. The mean blast ratio in the peripheral smear and bone marrow was $52.06 \pm 29.51$ and $86.30 \pm 15.01$, respectively (Table 1). 
Table 1.

Clinical characteristics and laboratory parameters of children

\begin{tabular}{lcc}
\hline Değişkenler & $\mathrm{n}(\%)$ \\
\hline Age (years) & & $4.5(3-10.2)$ \\
Gender (Female/Male) & F/M & $23 / 22(51 \% / 49 \%)$ \\
Median hemoglobin $(\mathrm{g} / \mathrm{l})$ & & $7.35(5.07-9.52)$ \\
Median leucosyte number $\left(10^{9} / \mathrm{L}\right)$ & & $10.95(4.85-41.78)$ \\
Median platelet number $\left(10^{9} / \mathrm{L}\right)$ & & $81.0(23.75-131.75)$ \\
Median sedimentation rate $(\mathrm{mm} / \mathrm{hr})$ & & $87.5(62-105.25)$ \\
Risk group & SRG & $18(40 \%)$ \\
& IRG & $21(47 \%)$ \\
& HRG & $6(13 \%)$ \\
Immuno-phenotyping & Pre-B & $37(82 \%)$ \\
& ALL & $4(9 \%)$ \\
& Pro-B & $4(9 \%)$ \\
Mean blast ratio in peripheral blood smear $(\%)$ & ALL & \\
Mean blast ratio in bone marrow smear $(\%)$ & T ALL & \\
\hline
\end{tabular}

SRG: Standart risk group, IRG: Intermediate risk group, HRG: High risk group

The median fibrinogen and total The lowest fibrinogen and total protein/albumin levels on the $15^{\text {th }}, 18^{\text {th }}, 21^{\text {st }}$, protein/albumin levels were observed on the $24^{\text {th }}, 27^{\text {th }}, 30^{\text {th }}$ and $33^{\text {rd }}$ days were significantly $21^{\text {st }}$ and $27^{\text {th }}$ days of chemotherapy (Figure 1 lower than the values of before treatment and 2). None of our patients developed a (Table 2).

$P$ values used for the comparison of fibrinogen, protein and albumin levels were presented in Table 3. serious bleeding complication. Thrombotic complication developed in three children $(9.3 \%)$. Two patients had deep vein thrombosis, one patient had central nervous system thrombosis.

Table 2

Changes in fibrinogen and total protein/albumin levels during the induction chemotherapy.

\begin{tabular}{lccc}
\hline & Fibrinogen $(\mathrm{mg} / \mathrm{dl})$ & Total protein $(\mathrm{mg} / \mathrm{dl})$ & Albumin $(\mathrm{mg} / \mathrm{dl})$ \\
\hline Before treatment & $386.70(255-521)$ & $6.4(6.04-6.80)$ & $4.34(4.20-4.60)$ \\
$12^{\text {th }}$ day & $147.0(108.0-184.30)$ & $6.3(6,10-6,60)$ & $4.28(3.80-4.30)$ \\
$15^{\text {th }}$ day & $106.0(84.5-128.0)$ & $5.70(5.40-6.30)$ & $4.0(3.70-4.30)$ \\
$18^{\text {th }}$ day & $88.0(63.60-109.80)$ & $5,59(5.20-5.70)$ & $3.85(3.50-4.20)$ \\
$21^{\text {th }}$ day & $72.0(51.60-103.20)$ & $5,50(4.90-5.90)$ & $3,70(3.45-4.10)$ \\
$24^{\text {th }}$ day & $86.0(51.0-124.80)$ & $5,50(4.90-6.0)$ & $3.70(3.30-4.0)$ \\
$27^{\text {th }}$ day & $82.60(52.0-101.0)$ & $5.30(5.07-5.70)$ & $3.58(3.25-3.83)$ \\
$30^{\text {th }}$ day & $84.0(56.0-138.0)$ & $5.60(5.20-5.80)$ & $3.70(3.330-3.90)$ \\
$33^{\text {rd }}$ day & $98.0(72.0-158.20)$ & $5,68(5.40-5.90)$ & $3.70(3.41-4.16)$ \\
\hline
\end{tabular}


Table 3.

$\mathrm{P}$ values used for the comparison of fibrinogen, protein and albumin levels

\begin{tabular}{|c|c|c|c|c|c|c|c|c|}
\hline & $12^{\text {th }}$ day & $15^{\text {th }}$ day & $18^{\text {th }}$ day & $21^{\text {th }}$ day & $24^{\text {th }}$ day & $27^{\text {th }}$ day & $30^{\text {th }}$ day & $33^{\text {rd }}$ day \\
\hline \multirow[t]{3}{*}{ Before treatment } & $>0.05$ & $<0.001$ & $<0.001$ & $<0.001$ & $<0.001$ & $<0.001$ & $<0.001$ & $<0.001$ \\
\hline & $>0.05$ & 0.006 & $<0.001$ & $<0.001$ & $<0.001$ & $<0.001$ & $<0.001$ & 0.001 \\
\hline & $>0.05$ & 0.018 & 0.006 & 0.001 & $<0.001$ & 0.004 & $<0.001$ & $<0.001$ \\
\hline \multirow[t]{3}{*}{$12^{\text {th }}$ day } & & 0.01 & 0.005 & $<0.001$ & 0.002 & $<0.001$ & $>0.05$ & $>0.05$ \\
\hline & & 0.008 & $<0.001$ & $<0.001$ & $<0.001$ & $<0.001$ & $<0.001$ & $<0.001$ \\
\hline & & 0.036 & 0.007 & 0.001 & $<0.001$ & $<0.001$ & $<0.001$ & $<0.001$ \\
\hline \multirow[t]{3}{*}{$15^{\text {th }}$ day } & & & $>0.05$ & $>0.05$ & $>0.05$ & $>0.05$ & $>0.05$ & $>0.05$ \\
\hline & & & $>0.05$ & $>0.05$ & $>0.05$ & $>0.05$ & $>0.05$ & $>0.05$ \\
\hline & & & 0.032 & 0.028 & 0.018 & 0.001 & 0.009 & 0.030 \\
\hline \multirow[t]{3}{*}{$18^{\text {th }}$ day } & & & & $>0.05$ & $>0.05$ & $>0.05$ & $>0.05$ & $>0.05$ \\
\hline & & & & $>0.05$ & $>0.05$ & $>0.05$ & $>0.05$ & $>0.05$ \\
\hline & & & & $>0.05$ & $>0.05$ & $>0.05$ & $>0.05$ & $>0.05$ \\
\hline \multirow[t]{3}{*}{$21^{\text {th }}$ day } & & & & & $>0.05$ & $>0.05$ & $>0.05$ & $>0.05$ \\
\hline & & & & & $>0.05$ & $>0.05$ & $>0.05$ & $>0.05$ \\
\hline & & & & & $>0.05$ & $>0.05$ & $>0.05$ & $>0.05$ \\
\hline \multirow[t]{3}{*}{$24^{\text {th }}$ day } & & & & & & $>0.05$ & $>0.05$ & $>0.05$ \\
\hline & & & & & & $>0.05$ & $>0.05$ & $>0.05$ \\
\hline & & & & & & $>0.05$ & $>0.05$ & $>0.05$ \\
\hline \multirow[t]{3}{*}{$27^{\text {th }}$ day } & & & & & & & $>0.05$ & $>0.05$ \\
\hline & & & & & & & $>0.05$ & $>0.05$ \\
\hline & & & & & & & $>0.05$ & $>0.05$ \\
\hline \multirow[t]{3}{*}{$30^{\text {th }}$ day } & & & & & & & & $>0.05$ \\
\hline & & & & & & & & $>0.05$ \\
\hline & & & & & & & & $>0.05$ \\
\hline
\end{tabular}

$1^{\text {st }}$ line; fibrinogen, $2^{\text {st }}$ line; total protein, $3^{\text {nd }}$ line; albumin

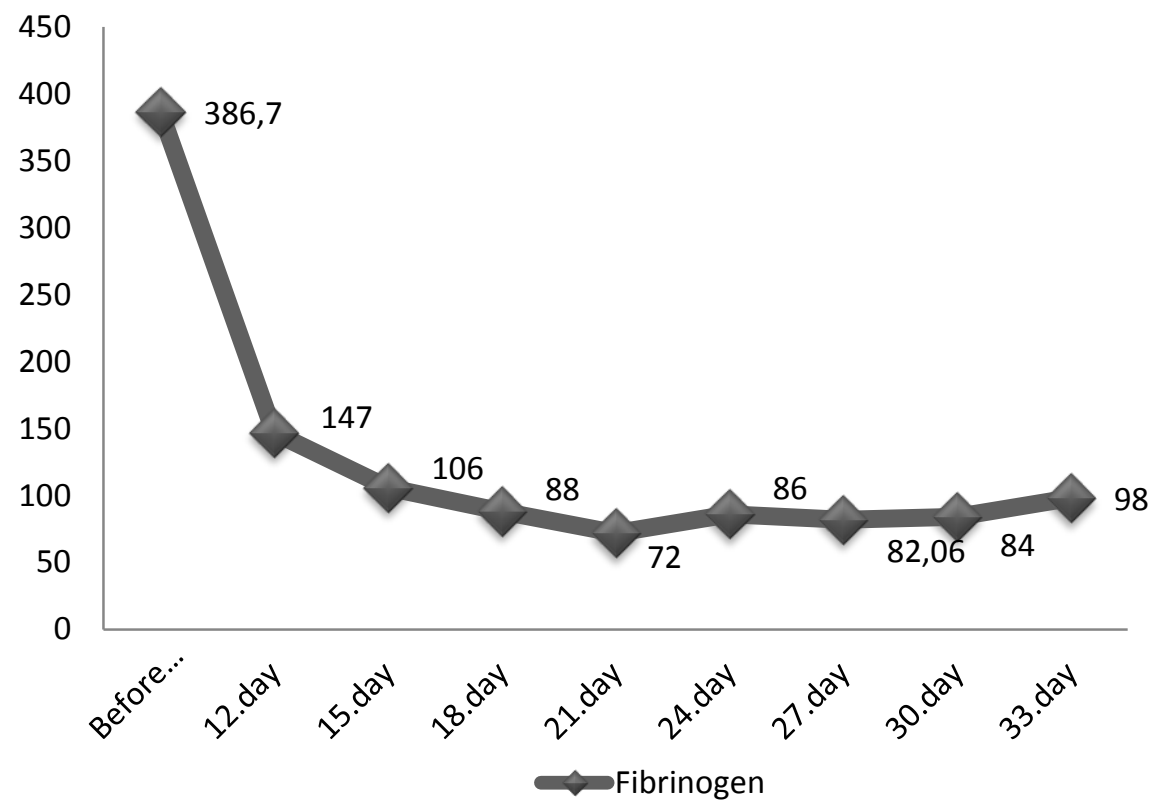

Figure 1.Median levels of fibrinogen during the induction chemotherapy 


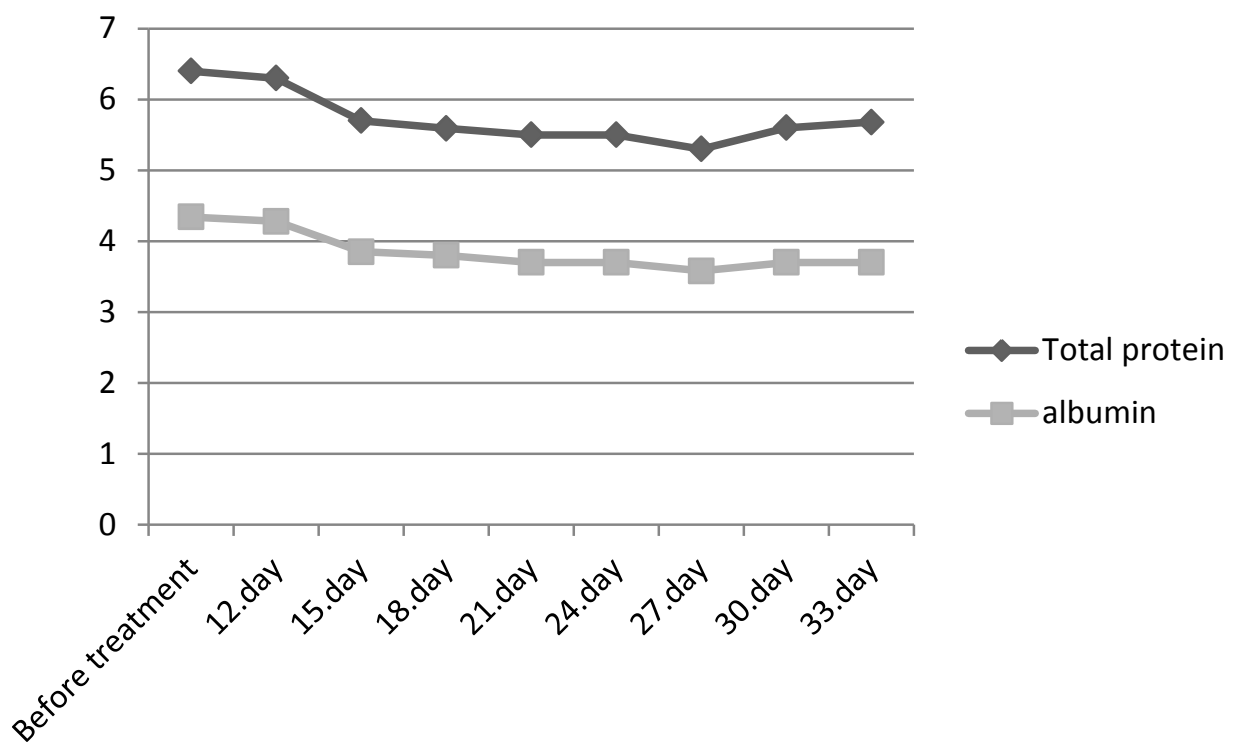

Figure 2. Median levels of total protein/albumin during the induction chemotherapy

\section{Discussion}

L-Asparaginase is an important chemotherapeutic agent used in pediatric leukemia. Previous study has been reported that treatment with L-Asparaginase causes widespread impairment of hemostasis by inhibiting biosynthesis of hepatic Lasparagine-dependent proteins (3). LAsparaginase leads to marked reduction of plasma antithrombin and fibrinogen levels and this effect may be associated with an increased tendency to bleeding or thrombosis $(3,11)$.

Giardona at al.(12) reported that antithrombin and fibrinogen levels dropped when Lasparaginase and steroid treatment were taken and that antithrombin and fibrinogen levels returned to normal after L-Asparaginase and steroid therapy were discontinued. They suggesting that the steroid and LAsparaginase had negative effects on antithrombin and fibrinogen.

In the study by Sutor et al.(9) conducted on 14 patients receiving the ALL/NHL BFM 90 protocol, the fibrinogen level was observed to fall to $148 \mathrm{mg} / \mathrm{dl}$ while receiving glucocorticoids alone during the induction phase, while the reduction in the fibrinogen levels continued more rapidly after starting LAsparaginase therapy after the $12^{\text {th }}$ day, reaching the lowest mean of $46 \mathrm{mg} / \mathrm{dl}$ on the $24^{\text {th }}$ day. According to the results of our study, median fibrinogen values are significantly reduced while under steroid treatment in the first 12 days of treatment (Figure 1). Since the hemostatic parameters are tested before the each infusion of L-Asparaginase, we may state that the reduced fibrinogen values on the $12^{\text {th }}$ day are not related to L-Asparaginase. Based on these results, we can say that the level of fibrinogen has already reduced before the start of L-Asparaginase treatment, and it continues to slightly decrease until the $21^{\text {st }}$ day (Figure 1).

The fact that the median fibrinogen values were higher in our patients compared to the BFM 90 protocol may be associated with the $50 \%$ reduction in the L-Asparaginase dose in the BFM 2009 protocol. In the study by Attarbaschi et al.(13) conducted on 16 patients treated according to the BFM 2000 protocol, fibrinogen and antithrombin values were observed to be less significantly reduced when L-Asparaginase was administered on a dose of $5000 \mathrm{u} / \mathrm{m}^{2} \times 8$ times with three-day intervals compared to a dose of $10.000 \mathrm{u} / \mathrm{m}^{2}$. The results of our study also support the results of this study.

In this study, the total protein and albumin levels were found to be significantly reduced in the first 15 days of induction chemotherapy. We are of the opinion that this decrease occurs may be due to the catabolic processes caused by the malignancy, as well as the accompanying nourishment problems 
and the suppression of the protein synthesis by the chemotherapeutic agents. We have not evaluated the malnutrition status of patients in this study. For this reason, we cannot say how much the effect of nutritional status on the reduction in protein and albumin levels.

Asparaginase and corticosteroid treatment in patients with ALL is associated with an increased risk of thrombotic complications (6).The frequency of thromboembolic complications $(9.3 \%)$ in our study was similar to those reported in literature. The reported incidence of venous thromboembolism in childhood ALL varies from $1.1 \%$ to $36.7 \%$ with an overall average of $3.2 \%(7,8)$. A large retrospective multicentre survey of 1100 children treated on the Berlin Frankfurt
Munster (BFM)-90 trial found 19 (1.7\%) with thromboses, whilst a smaller prospective study of similarly treated children showed a higher incidence of $14.3 \%(9,10)$.

\section{Conclusion}

Our results showed a significant decrease in fibrinogen and protein albumin levels during induction chemotherapy. Although the dose of L-Asparaginase has been reduced, thrombotic complications remain a significant problem.

Still, prospective studies including larger numbers of patients are needed in order to demonstrate the extent of the changes in the antithrombotic factor levels and determine the risk of these patients in terms of thrombotic complications.

\section{REFERENCES}

1. Clavell, L., Gelber, R., Cohen, H., et al. (1986) Four-agent induction and intensive asparaginase therapy for treatment of childhood acute lymphoblastic leukemia. N Engl J Med, 315(11), 657-63.

2. Duval, M., Suciu, S., Ferster, A., et al. (2002) Comparison of Escherichia coli-asparaginase with Erwinia-asparaginase in the treatment of childhood lymphoid malignancies: results of a randomized European Organization for Research and Treatment of Cancer-Children's Leukemia Group phase 3 trial. Blood, 99(8), 2734-9.

3. Mitchell, L.G., Halton, J.M., Vegh, P.A., et al.(1994) Effect of disease and chemotherapy on hemostasis in children with acute lymphoid leukemia. Am J Pediatr Hematol Oncol, 16(2), 1206.

4. De Stefano, V., Za, T., Ciminello, A., Betti, S., Rossi, E. (2015) Haemostatic alterations induced by treatment with asparaginases and clinical consequences. Thromb Haemost, 113(2), 247-61.

5. Appel, I.M., Hop, W.C., van Kessel-Bakvis, C., Stigter, R., Pieters, R. (2008) L-Asparaginase and the effect of age on coagulation and fibrinolysis in childhood acute lymphoblastic leukemia. Thromb Haemost, 100(2), 330-7.

6. Rozen, L., Noubouossie, D., Dedeken, L., et al. (2017) Different profile of thrombin generation in

12. therapy and clinical outcome: the CAPELAL study. Haematologica, 93(10), 1488-94.

13. Giordano, P., Molinari, A.C., Del Vecchio, G.C., et al. (2010) Prospective study of hemostatic alterations in children with acute lymphoblastic leukemia. Am J Hematol, 85(5), 325-30. children with acute lymphoblastic leukemia treated with native or pegylated asparaginase: A cohort study. Pediatr Blood Cancer, 64(2), 294-01.

7. Caruso, V., Iacoviello, L., Di Castelnuovo, A., et al. (2006) Thrombotic complications in childhood acute lymphoblastic leukemia: A meta-analysis of 17 prospective studies comprising 1752 pediatricpatients. Blood, 108,2216-22.

8. Payne, J.H., Vora, A.J. (2007) Thrombosis and acute lymphoblastic leukaemia. Br J Haematol, $138,430-45$.

9. Sutor, A.H., Niemeyer, C., Sauter. S., et al. (1992) Changes in blood coagulation in treatment with ALL-BFM-90 and NHL-BFM-90 protocols. Klin Padiatr, 204(4), 264-73.

10. Korte, W., Feldges, A., Baumgartner, C., Ullmann, S., Niederer, V., Schmid, L. (1994) Increased thrombin generation during fibrinogen and platelet recovery as an explanation for hypercoagulability in children with L-asparaginase therapy for ALL or NHL: a preliminary report. Klin Padiatr, 206, 33133.

11. Hunault- Berger, M., Chevallier, P., Delain, M., et al. (2008) Changes in antithrombin and fibrinogen levels during induction chemotherapy with Lasparaginase in adult patients with acute lymphoblastic leukemia or lymphoblastic lymphoma. Use of supportive coagulation 14. Attarbaschi, A., Mann, G., Kronberger, M., Witt, V., Gadner, H., Dworzak, M.(2003) Effects of dose-reduced Medac L-asparaginase on coagulation in trial ALL-BFM 2000. Klin Padiatr, 215(6), 3216. 